\title{
ZOOPLANKTON STRUCTURE IN TWO INTERCONNECTED PONDS: SIMILARITIES AND DIFFERENCES
}

\author{
Maria Špoljar ${ }^{1}$, Tea Tomljanović ${ }^{2}$, Tvrtko Dražina ${ }^{1}$, Jasna Lajtner ${ }^{1}$, Helena Štulec $^{3}$, Daniel \\ Matulić $^{2}$, Jelena Fress| ${ }^{4}$
}

${ }^{1}$ University of Zagreb, Faculty of Science, Department of Biology, Zoology, Zagreb, Croatia

${ }^{2}$ University of Zagreb, Faculty of Agriculture, Department of Fisheries, Beekeeping, Game Management and Special Zoology, Zagreb, Croatia

${ }^{3}$ Ministry of construction and physical planning, Directorate for construction and energy efficiency in the buildings sector, Zagreb, Croatia

${ }^{4}$ Dvokut ECRO Ltd., Zagreb, Croatia

*Corresponding Author, Email: maria.spoljar@biol.pmf.hr

\section{ARTICLE INFO}

Received: 11 January 2016

Received in revised form: 1 February 2016

Accepted: 3 February 2016

Available online: 18 February 2016

\section{ABSTRACT}

The research of zooplankton diversity, abundance and trophic structure was conducted during the summer period in pelagial zone on the longitudinal profile of the Sutla River Backwater. Investigated site consists of two interconnected basins: transparent Upper Basin with submerged macrophytes and turbid Lower Basin without macrophytes in the littoral zone. In the Upper Basin, abundance and diversity of zooplankton in the pelagial was higher in comparison to the Lower Basin, with prevailing species of genus Keratella as microfilter-feeder, and genera of Polyartha and Trihocerca as macrofilterfeeder rotifers. On the contrary, in the Lower Basin, crustaceans dominated in abundance. Microfilter-feeder cladoceran (Bosmina longirostris) and larval and adult stages of macrofilter-feeder copepod (Macrocyclops albidus) prevailed in the Lower Basin. Fish predation pressure was more pronounced in the pelagial of the Upper Basin, indicated by low cladoceran abundance in the surface layer. Although the studied basins were interconnected, results indicate significant (Mann-Whitney $U$ test, $p<0.05$ ) differences in the zooplankton structure as a potential result of the macrophyte impact on environmental conditions and fish predation pressure.

Špoljar, M., Tomljanović, T., Dražina, T., Lajtner, J., Štulec, H., Matulić, D. (2016): Zooplankton structure in two interconnected ponds: similarities and differences. Journal of Fisheries 74, 6-13. DOI: 10.1515/cjf-2016-0002

\section{INTRODUCTION}

Shallow lakes have an exceptional ecological significance (biodiversity of invertebrates, fish, water birds), but they are often neglected in limnological studies (Céréghino et al., 2008). Anthropogenic impacts frequently lead to the eutrophication and acidification of these habitats, and the introduction of invasive plants and animals results in reduced biodiversity (Kruk et al., 2009). Besides ecological significance, shallow lakes have cultural and economic value, manifested through sport, recreation and tourism. Eutrophication, as the most pronounced recent issue, is facilitated by multiple anthropogenic impacts: leaching of natural and mineral fertilizers from agricultural land, inflow of municipal and industrial waste water, fishing and recreation. In response to the increased nutrients, especially phosphorus, most of the shallow lakes have changed from transparent to the turbid state (Scheffer et al., 1993; Beklioglu et al., 2003). Turbid waters are characterized by the increasing of planktivorous and bentivorous fish, higher biomass of phytoplankton and sediment resuspension caused by wind and fish. On the other hand, transparent waters are characterized by high 
biomass of submerged macrophytes and abundant algaevorous zooplankton (large-bodied crustacean grazers). Macrophytes can significantly alter abiotic (temperature, oxygen concentration, light intensity) and biotic (food availability, competition, predation) factors in aquatic ecosystems (Cazzanelli et al., 2008; Špoljar et al., 2012). Their stands have an important role in sediment stabilization, reduction of coastal erosion and in the assimilation of nutrients into biomass, which results in decreasing of phytoplankton biomass and trophic level. Concurrently, macrophytes increased habitat diversity, provided plenty and diverse food resources, and refuge from predators (larvae and adult fish insects) for the zooplankton and benthic invertebrates (Estlander et al., 2009; Špoljar, 2013).

Fish, as visual predators, are one of the main factors modifying the abundance, diversity and horizontal migration of the zooplankton in shallow lakes. Thus, littoral zone with submerged macrophytes reduces fish predation and enables refuge for the potential prey in pelagial such as large-bodied algaevorous cladocerans (Jeppesen et al., 1999; Estlander et al., 2009). Otherwise, increased turbidity decreases fish predation in pelagial as well as the importance of macrophyte stands as a refuge for zooplankton. In these conditions, small-bodied detritivorous cladocerans and rotifers prevailed in the pelagial of turbid waters (Špoljar et al., 2011). The zooplankton structure in interconnected lakes possesses patterns that vary depending on the trophic level and biotic interactions in accordance with the theory of alternative states, i.e. transparent v. turbid state (Scheffer et al., 1993; Cotteine et al., 2001). The composition of the zooplankton in these lakes is also affected by the possibility of dispersion and colonization (Gliwicz et al., 2000; Cottenie et al., 2001; Michels et al., 2001).

The aim of this study was to determine similarities and differences in zooplankton structure between two interconnected basins in the backwater of the Sutla River, based on the following community parameters: (i) diversity and abundance of main zooplankton groups; (ii) abundances of functional feeding guilds; and (iii) fish predation.
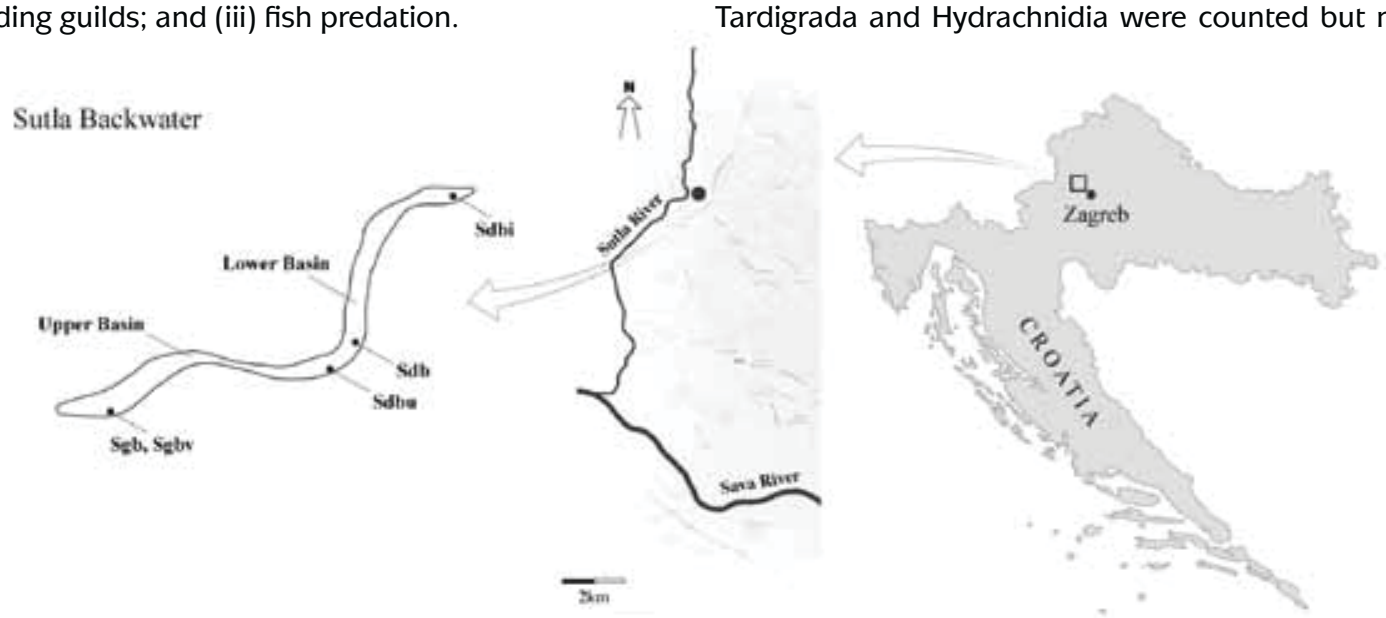

Fig 1. Location of study area and sampling sites in the Sutla River Backwater

\section{MATERIALS AND METHODS}

This research was conducted from May to October 2013 in the backwater of the Sutla River, located in the northwest of Croatia. Sutla River Backwater consists of two interconnected basins (Fig. 1). Transparent Upper Basin (UB; width$\max =13 \mathrm{~m}$ length $\max _{\max }=124 \mathrm{~m}$, depth $\mathrm{m}_{\max }=2.75 \mathrm{~m}$ ) has a coverage of submerged macrophytes of $32 \pm 12 \%$, and hornwort (Ceratophyllum demersum L., 1753) as dominant species. Turbid Lower Basin (LB width $_{\text {max }}=14 \mathrm{~m}$ length ${ }_{\text {max }}=188$ $\mathrm{m}$, depth max $=4.15 \mathrm{~m}$ ) is without macrophytes in the littoral zone. Both basins are under distinct anthropogenic impacts, i.e. leaching from the surrounding meadows and fields. The Lower Basin is also exposed to the intensive sport fishing: fish stocking, the use of protein baits and food supplements. Samples from the UB were taken in the pelagial at two stations: the surface layer (Sgb) and bottom water layer (Sgbv). LB samples were collected at three stations: the water inflow from the UB to the LB (Sdbu), the surface water layer $(\mathrm{Sdb})$ and the water outflow to the channel connected with the Sutla River (Sdbi).

Samples were taken on nine occasions, monthly in May, September and October, and biweekly during June, July and August. Exception was station Sdbu, where analyses started in the second half of July. From each station samples were collected in triplicate; each $30 \mathrm{~L}(3 \times 10 \mathrm{~L})$ sample of water was filtered through $26 \mu \mathrm{m}$ mesh plankton net, except at the (Sgbv) station where a total of $15 \mathrm{~L}(3 \times 5 \mathrm{~L})$ of water was filtered by the Van Down sampler (volume $5 \mathrm{~L}$ ).

A mean of triplicate was used as a single data point for a given occasion $(n=41)$. Zooplankton was fixed in $4 \%$ formalin, determined and counted. In this study, qualitative and quantitative compositions of three planktonic groups - rotifers (Rotifera), copepods (Copepoda) and cladocerans (Cladocera) - were taken into consideration, determined to the genus or species level using determination keys: Voigt and Koste (1978), Margaritora (1983) and Einsle (1993). Bdelloidea, Ostracoda, Nematoda, Gastrotricha, Oligochaeta, ardigrada and Hydrachnidia were counted but not identi- 
fied. For quantitative analysis, entire sample was counted using a Petri dish under an Opton-Axiovert 35 inverted microscope $(200 \times, 400 \times)$. Fish were collected at sampling stations Sgb, Sdbu and Sdb by electrofishing and their abundance was shown as catch per unit effort of 15 min during daylight hours (Hans Grassl EL 63 II, 220/440 V, 17.8/8.9 A).

The following parameters were measured in situ: temperature, oxygen concentration (WTW OXI 96), pH (WTW 330i) and conductivity ( $\mathrm{HACH}$ sension 5 ). For analyses of chemical parameters, $3 \mathrm{~L}$ of non-filtered water were taken in bottles at the same study stations as the zooplankton samples. All nutrients, ortophosphates, total phosphorus, nitrates and Kjeldahl total nitrogen were determined by APHA, 1998. Nitrites and ammonium were measured using ion chromatograph (Dionex ICS-3000). Chemical oxygen demand (COD) was measured by the oxidation of dissolved organic matter, using $\mathrm{KMnO}_{4}$ (results expressed as $\mathrm{mg} \mathrm{O}_{2 \mathrm{Mn}} \mathrm{L}^{-1}$ ). Phytoplankton biomass (measured as chlorophyll $a$ ) and concentration of particulate organic matter (POM, measured as ash free dry mass, AFDM) were considered as food resources for the main zooplanktonic groups. Chlorophyll $a(\mathrm{Chl} a)$ concentration was analysed by ethanol extraction according to Nusch (1980). Ash free dry mass was determined from 30 $\mathrm{L}$ filtered water samples (mesh $26 \mu \mathrm{m}$ ); these were dried at $104^{\circ} \mathrm{C}$ for $4 \mathrm{~h}$ on ceramic dishes and ashed at $600^{\circ} \mathrm{C}$ for $6 \mathrm{~h}$. Macrophyte coverage was calculated according to Špoljar et al. (2011). Trophic state index based on transparency (TSI ${ }_{S D}$ ) was determined according to Carlson (1977). Rotifers were divided in functional feeding guilds (trophic groups) as microfilter-feeders (detritivorous), macrofilter-feeders (algivorous) and predators (Karabin, 1985; Špoljar et al., 2007, 2012). Generally, crustacean trophic structure was considered on the taxonomic level, because cladocerans were presented by microfilter-feeders, and larval and adult stages of copepods were presented by macrofilter-feeders. Prior to statistical analysis, all abiotic and biotic data were logarithmically transformed $[\log (x+1)]$ and their normality was checked using Shapiro-Wilk's test. As this test suggested that the data did not follow a normal distribution, even after transformation, a nonparametric Kruskal-Wallis test (comparison among multiple independent samples) or a MannWhitney $U$ test (comparison between two independent samples) for environmental parameters and biotic components were used. For an explanation of relationships between the abundance of three zooplankton groups and environmental variables (conductivity, $\mathrm{pH}, \mathrm{Chl} a, \mathrm{AFDW}$ ), a Spearman correlation coefficient was used. For statistical data analysis the STATISTICA software package was used (StatSoftÓ).

\section{RESULTS}

$\mathrm{TSI}_{\mathrm{SD}}$ was $60 \pm 5.5$ in the UB, indicating a transition of mezotrophic to the eutrophic level, while $\mathrm{TSI}_{\mathrm{SD}}$ was $70 \pm 2$ in the
LB, indicating a transition of eutrophic to the hypertrophic level. Minimum, maximum and average values of physicochemical parameters and significance of their spatio-temporal oscillations are shown in Table 1. Transparency, POM and phytoplankton biomass were significantly higher in the UB in comparison to the LB, and the opposite was established for the conductivity.

During the study period 37 zooplankton taxa were determined. Rotifers achieved the highest diversity (27 species) and dominated in abundance ( $80 \%$ ) of the UB, while planktonic crustaceans (cladocerans and copepods) dominated in the LB (Fig. 2).

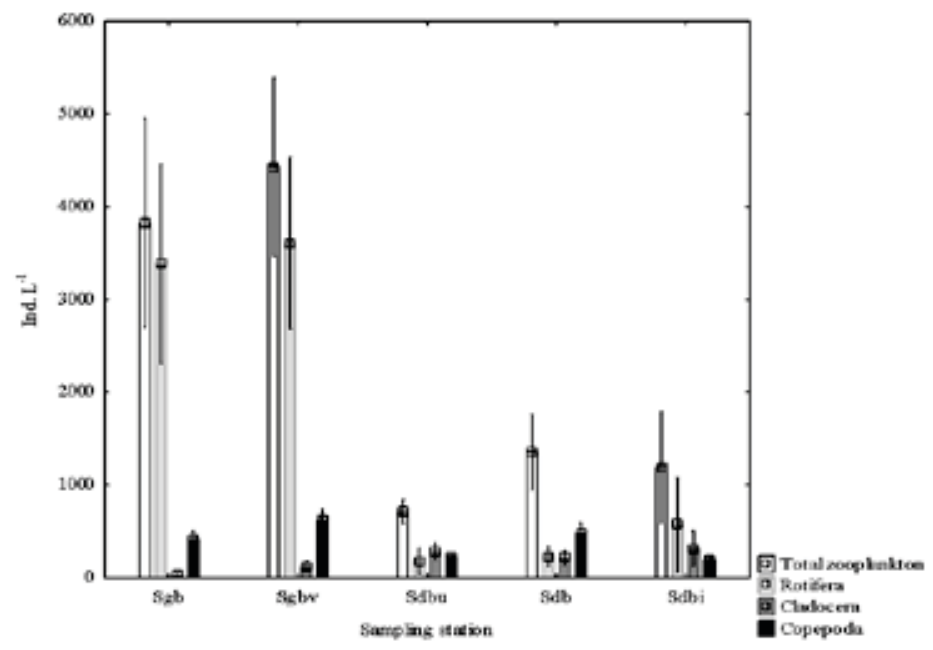

Fig 2. Spatial oscillations in abundance $(n=3 \pm S E)$ of total zooplankton, rotifers, cladocerans and copepods on the longitudinal profile of the Sutla Backwater

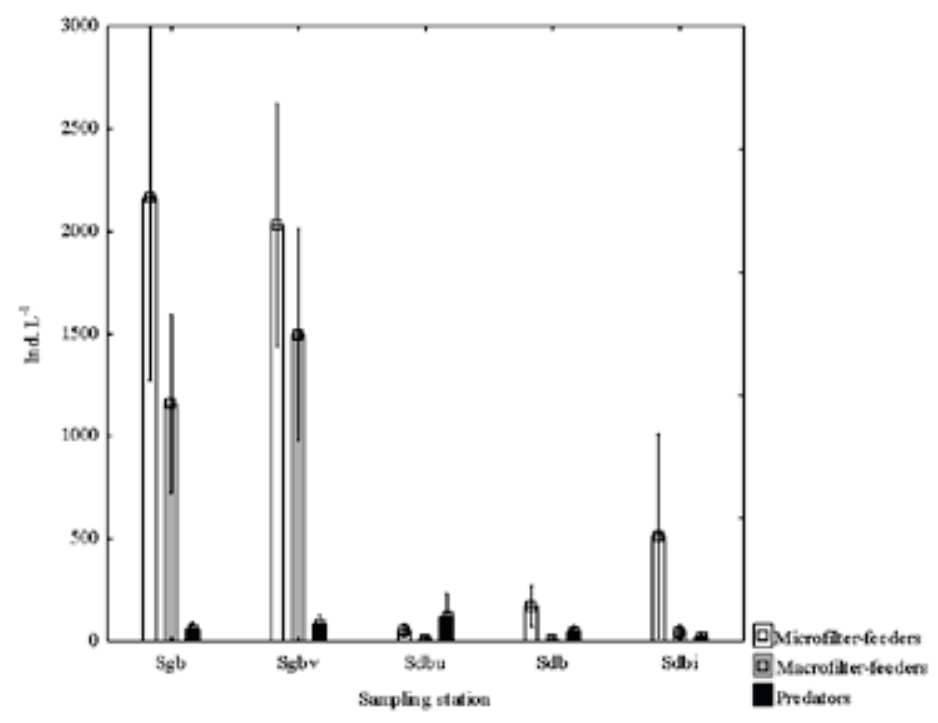

Fig 3. Spatial oscillations of rotifer trophic groups: microfilterfeeders, macrofilter-feeders and predators $(n=9 \pm$ $\mathrm{SE}$ ) on the longitudinal profile of the Sutla Backwater 
Table 1. Minimum (Min), maximum (Max), mean value and standard deviation (SD) of environmental parameters and the significance of spatial and temporal oscillations on the longitudinal profile of the Sutla River Backwater (KruskalWallis test, $\mathrm{p}<0.05$; multiple comparison post hoc test, $\mathrm{n}=41$ )

\begin{tabular}{|c|c|c|c|c|c|c|c|c|c|c|c|}
\hline \multirow{2}{*}{$\begin{array}{l}\text { Envarimenal } \\
\text { parametars }\end{array}$} & \multirow[b]{2}{*}{ Min } & \multirow[b]{2}{*}{ Max } & \multirow[b]{2}{*}{ Mean } & \multirow[b]{2}{*}{ \pm} & \multirow[b]{2}{*}{ S SD } & \multicolumn{3}{|c|}{ Spatial oscillations } & \multicolumn{3}{|c|}{ Temporal oscillations } \\
\hline & & & & & & $\mathrm{H}$ & $p$ & $\begin{array}{l}\text { Multiple } \\
\text { comparison }\end{array}$ & $\mathrm{H}$ & $p$ & $\begin{array}{c}\text { Multiple } \\
\text { comparison }\end{array}$ \\
\hline Depht (m) & 0.4 & 4.2 & 1.8 & \pm & 0.9 & 28.8 & 0 & $\begin{array}{l}\text { Sdbi }<\text { Sdb. } \\
\text { Sgb. Sgbv } \\
\text { Sdb }<\text { Sdbu }\end{array}$ & 5.8 & ns & \\
\hline Transparancy $_{S D}(\mathrm{~m})$ & 0.3 & 1.5 & 0.8 & \pm & 0.4 & 22.0 & 0.0002 & $\begin{array}{l}\mathrm{Sdb}<\mathrm{Sgb} . \\
\text { Sgbv }\end{array}$ & 10.9 & ns & \\
\hline Temperature $\left({ }^{\circ} \mathrm{C}\right)$ & 13.1 & 26.6 & 20.1 & \pm & 3.7 & 1.1 & ns & & 36.9 & $\begin{array}{c}0 \\
V I / 2>V I / 1 . I X\end{array}$ & $\begin{array}{c}X<\mathrm{VI} / 2 \\
\mathrm{VII} / 2 . \mathrm{VIII} / 1\end{array}$ \\
\hline $\begin{array}{l}\text { Concentration of } \\
\text { dissolved } \mathrm{O}_{2}\left(\mathrm{mg} \mathrm{O}_{2} \mathrm{~L}^{-1}\right)\end{array}$ & 2.0 & 9.2 & 5.2 & \pm & 1.8 & 2.6 & ns & & 25.9 & 0.0011 & $\begin{array}{c}\mathrm{VIII} / 1<\mathrm{VI} / 1 \\
\mathrm{VI} / 2\end{array}$ \\
\hline \multirow[t]{2}{*}{ pH } & 7.4 & 8.4 & 7.7 & \pm & 0.2 & 7.8 & ns & & 17.5 & 0.0254 & $\mathrm{X}>\mathrm{VI} / \mathrm{1} \cdot \mathrm{VI} / 2$ \\
\hline & & & & & & & & $\begin{array}{l}\mathrm{Sgb}<\mathrm{Sdb} \\
\quad \mathrm{Sdbi}\end{array}$ & & & \\
\hline \multirow[t]{2}{*}{ Conductivity } & 324.0 & 681.0 & 526.9 & \pm & 122.7 & 27.0 & 0 & Sgbv $<$ Sdbi & 2.6 & ns & \\
\hline & & & & & & & & $\begin{array}{l}\text { Sdbi > Sgb. } \\
\text { Sgbv }\end{array}$ & & & \\
\hline 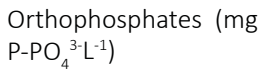 & 0.025 & 1.011 & 0.127 & \pm & 0.176 & 8.0 & ns & & 23.5 & 0.0028 & $\mathrm{VII} / 1>\mathrm{VI} / 2$ \\
\hline $\begin{array}{l}\text { Total phosphorus (mg } \\
\mathrm{P} \mathrm{L}^{-1} \text { ) }\end{array}$ & 0.144 & 1.834 & 0.472 & \pm & 0.287 & 7.7 & ns & & 13.8 & ns & \\
\hline $\begin{array}{l}\text { Ammonia (mg } \\
\mathrm{N}-\mathrm{NH}_{3}{ }^{-1} \text { ) }\end{array}$ & 0.004 & 0.566 & 0.150 & \pm & 0.131 & 0.6 & ns & & 28.4 & $\begin{array}{c}0.0004 \\
\mathrm{VI} / 1>\mathrm{VIIII} / 1 \\
\mathrm{VIIII} / 2\end{array}$ & $\begin{array}{l}\mathrm{V}>\mathrm{VIII} / 1 \\
\mathrm{VIII} / 2\end{array}$ \\
\hline 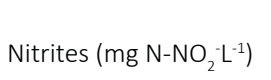 & 0.024 & 0.875 & 0.220 & \pm & 0.205 & 1.7 & ns & & 31.5 & 0.0001 & $\begin{array}{l}V>V I I I / 1 \\
V I I I / 2\end{array}$ \\
\hline $\begin{array}{l}\text { Nitrates (mg N-NO }{ }_{3}^{-} \\
\left.L^{-1}\right)\end{array}$ & 0.002 & 0.117 & 0.022 & \pm & 0.023 & 6.7 & ns & & 19.0 & 0.015 & $\mathrm{VII} / 2<\mathrm{V}$ \\
\hline $\begin{array}{l}\text { Total nitrogen (mg } \\
\mathrm{N} \mathrm{L}^{-1} \text { ) }\end{array}$ & 0.248 & 2.518 & 1.189 & \pm & 0.579 & 1.5 & ns & & 32.0 & $\begin{array}{c}0.0001 \\
x<\text { VI/1. VIII/2 }\end{array}$ & $V>I X . X$ \\
\hline $\mathrm{DOM}\left(\mathrm{mg} \mathrm{O}_{2 \mathrm{Mn}} \mathrm{L}^{-1}\right)$ & 14.220 & 38.552 & 21.582 & \pm & 6.435 & 4.7 & ns & & 33.0 & $\begin{array}{c}0.0001 \\
I X<V \mid I / 2\end{array}$ & $\begin{array}{l}V>V I I / 1 . \\
I X . X\end{array}$ \\
\hline 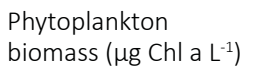 & 0.296 & 150.302 & 26.811 & \pm & 30.738 & 10.5 & 0.031 & Sdb $<$ Sgbv & 7.1 & ns & \\
\hline POM (mg AFDM L L-1) & 0.303 & 9.950 & 1.960 & \pm & 2.025 & 2.1 & 0.46628 & $\begin{array}{l}\text { Sgbv> Sdb, } \\
\text { Sdbu }\end{array}$ & 24.8 & ns & \\
\hline
\end{tabular}

${ }^{*}$ ns - non significant

Within rotifers and cladocerans of both basins, microfilterfeeders prevailed (Fig. 3). Among rotifers, Keratella cochlearis (Gosse, 1851) and Trichocerca similis (Wierzejski, 1893) dominated, within crustaceans Bosmina longirostris (O.F. Müller, 1776) from cladocerans and nauplii and copepodites of copepods.

In the spatial oscillations of the zooplankton structure (diversity, abundance and trophic groups), significant differences were established (Table 2). Overall, sampling stations in the UB obtained higher diversity and abundance compared to those in the LB (Mann-Whitney $U$ test, $p<0.05$ ), except cladoceran abundance which achieved higher values in the LB (Mann-Whitney U test, $Z=-2.90, p=0.003$ ).

In this basin, crustaceans significantly contributed and highly positively related to the zooplankton total abundance $(r=$ $0.72 ; p<0.05)$. Temporal oscilations of the zooplankton structure were not statistically significant (Kruskal-Wallis test, $p>0.05$ ). Considering fish, 15 different species were noted, 11 were cyprinids, two perciformes and one of catfish and pikes (Fig. 4). The abundance and diversity of fish did 
Table 2. The significance of spatial differences in the zooplankton diversity and abundance among sampling stations on the longitudinal profile of the Sutla Backwater (Kruskal-Wallis test, $p<0.05$; multiple comparison post hoc test, $\mathrm{n}=41$ )

\begin{tabular}{|c|c|c|c|}
\hline & $\mathbf{H}$ & $\mathbf{p}$ & Multiple comparison \\
\hline Zooplankton diversity & 15.59 & 0.0036 & Sgbv $>$ Sdbu \\
\hline Total zooplankton & 16.35 & 0.0026 & Sgbv $>$ Sdbi \\
\hline Rotifera & 24.26 & 0.0001 & Sgbv>Sdbu, Sdb, Sdbi \\
\hline $\begin{array}{l}\text { Keratatella } \\
\text { cochlearis }\end{array}$ & 23.85 & 0.0001 & Sgb, Sgbv>Sdbu, Sdbi \\
\hline Trihocerca similis & 30.74 & 0.0001 & $\begin{array}{l}\text { Sgbv }>\text { Sdbu, Sdb, Sdbi } \\
\quad S g b>S d b, S d b i\end{array}$ \\
\hline Cladocera & 11.28 & 0.0236 & Sdbu>Sgb \\
\hline Copepoda & 11.92 & 0.018 & Sgbv>Sdbi \\
\hline Rotifera microfilter-feeders & 19.52 & 0.0006 & $\begin{array}{l}\text { Sgbv }>\text { Sdbu, Sdbi } \\
\text { Sgb }>\text { Sdbi }\end{array}$ \\
\hline Rotifera macrofilter-feeders & 28.11 & 0.0001 & $\begin{array}{l}\text { Sgbv }>\text { Sdbu, Sdb, Sdbi } \\
\text { Sgb }>\text { Sdbu, Sdbi }\end{array}$ \\
\hline
\end{tabular}
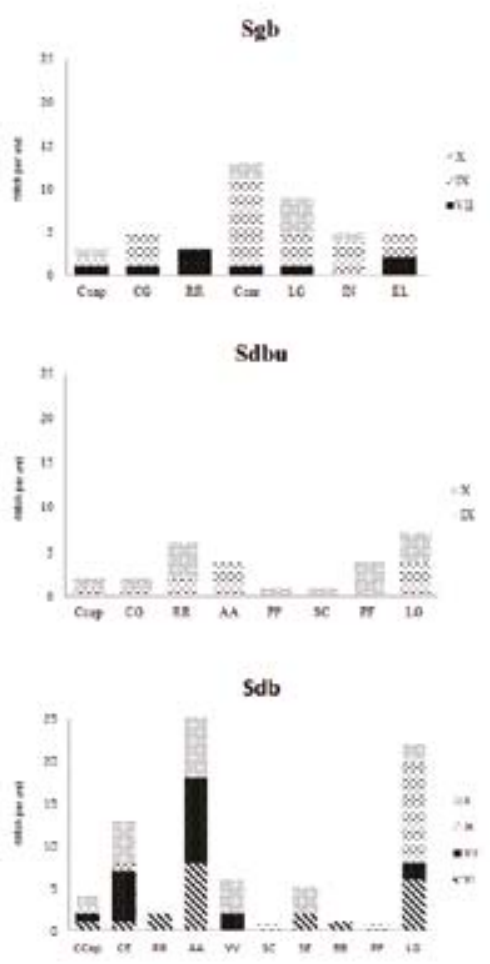

Fig 4. Oscillations in fish abundance and diversity on sampling stations Sgb, Sdbu and Sdb during the study period. Abbreviations: CCap Common carp (Cyprinus carpio); CE Loach (Cobitis elongata); CG Prussian carp (Carassius gibelio); RR Common roach (Rutilus rutilus); CCar Crucian carp (Carassius carassius); AA Bleak (Alburnus alburnus); PP Stone moroko (Pseudorasbora parva); VV Vimba bream (Vimba vimba); SC Chub (Squalius cephalus); SE Roach (Scardinius erythrophtalmus); BB White bream (Blicca bjoerkna); PF European perch (Perca fluviatilis); LG Pumpkinseed (Lepomis gibbosus); IN Brown bullhead (Ictalurus nebulosus); EL Pike (Esox luciuss) not show any statistically significant oscillations in the spatial and even temporal scale (Kruskal-Wallis test, $p>0.05$ ). In the environmental-biocoenotic interactions, macrophyte coverage positively correlated with transparency $(r=0.59 ; p$ $<0.05)$, phytoplankton biomass $(r=0.47 ; p<0.05)$ and POM $(r=0.58 ; p<0.05)$. Transparency and macrophyte coverage $(r=0.69 ; p<0.05)$ positively affected zooplankton diversity and negatively impacted cladoceran abundance in pelagial (macrophyte coverage: cladocerans $r=-0.52 ; p<0.05$ ).

Microfilter-feeder rotifers, i.e. Keratella cochlearis, were in direct competition for food and space with microfilter-feeder cladocerans, indicated by their negative correlation. In the less transparent $\mathrm{LB}$, the concentration of POM positively influenced the cladoceran abundance $(r=0.68 ; p<0.05)$. Fish negatively impacted total zooplankton as well as abundance of a particular group (Table 3 ).

\section{DISCUSSION}

Zooplankton structure was studied in two interconnected basins of the Sutla River Backwater: the UB, densely covered with submerged macrophytes (i.e. hornwort) and the LB, without macrophytes. The higher transparency in the UB can be explained by the presence of submerged macrophytes that prevented resuspension of sediment and reduced nutrient concentrations which commonly stimulate phytoplankton production and turbidity (Horppila and Nurminen, 2005; Špoljar, 2013). Significantly higher POM value in the UB originated from hornwort stem fragments. Instead of presence of submerged macrophytes, higher concentration of phytoplankton biomass in the UB could be induced by abundance of detritivorous species that feed on suspended organic matter and not on algae (Jeppesen et al., 1999). Higher turbidity in the LB was strongly associated 
Table 3. Spearman coefficient correlations $(p<0.05, n=41)$ for abiotic and biotic interactions on the longitudinal profile of the Sutla Backwater

\begin{tabular}{|c|c|c|c|c|c|c|}
\hline & Transparency & $\begin{array}{c}\text { Phytoplankton } \\
\text { biomass }\end{array}$ & POM & Cladocera & Copepoda & Fish \\
\hline & \multicolumn{6}{|c|}{$r$} \\
\hline Transparency & - & ns & ns & -0.46 & 0.46 & ns \\
\hline Phytoplankton biomass & ns & - & 0.51 & ns & 0.48 & ns \\
\hline POM & ns & 0.51 & - & ns & 0.41 & ns \\
\hline Zooplankton diversity & 0.32 & 0.50 & 0.63 & -0.54 & 0.37 & ns \\
\hline Total zooplankton & 0.44 & 0.55 & 0.62 & ns & 0.66 & -0.38 \\
\hline Rotifers & 0.55 & 0.49 & 0.55 & 0.52 & 0.41 & ns \\
\hline Keratatella cochlearis & 0.60 & 0.40 & 0.47 & -0.49 & 0.38 & ns \\
\hline Trihocerca similis & 0.57 & 0.48 & 0.62 & -0.48 & 0.41 & ns \\
\hline Crustracea & ns & ns & 0.32 & 0.34 & 0.78 & -0.50 \\
\hline Cladocera & -0.46 & ns & ns & - & ns & ns \\
\hline Copepoda & 0.46 & 0.48 & 0.41 & ns & - & -0.43 \\
\hline Rotifera microfilter-feeders & ns & ns & ns & -0.44 & 0.44 & ns \\
\hline Rotifera macrofilter-feeders & ns & ns & ns & -0.53 & ns & ns \\
\hline
\end{tabular}

*ns - non significant

with DOM, POM and inorganic matters. It prevented light penetration and development of submerged macrophytes, thus sediment resuspension was higher (Søndergaard et al., 2007; Feldmann and Nõges, 2007). Also, higher abundance of benthic fish in the LB stimulates turbidity: loach and carp (Mičetić et al., 2008), for example, facilitated bioturbation and prevented macrophytes rooting.

Higher abundance (UB $4129 \pm 3064$ ind $L^{-1}$, LB $1152 \pm 1341$ ind $\mathrm{L}^{-1}$ ) and diversity (UB $15 \pm 4$ taxa, LB $10 \pm 3$ taxa) of zooplankton in the UB (Mann-Whitney $U$ test, $p<0.05$ ), compared to the LB, can be explained by the presence of macrophyte stands in the littoral zone of UB, where many zooplankton organisms find refuge and food resources. Therefore, our results are in accordance with other studies in macrophytes-zooplankton relationships (Jeppesen et al., 1999; Estlander et al., 2009). Mainly small-bodied detritivorous rotifers (Keratella cochlearis, K. quadrata, Anuaraeopsis fissa, Filinia longiseta) were presented in the surface water layer of the UB. Due to their small body size and various protective mechanisms (sharp lorica extensions), they successfully avoided predation from adult planktivorous fish and achieved abundant and dominant populations in the UB (Stemberger and Gilbert, 1984; Špoljar et al., 2011). Zooplankton abundance in bottom water layer of the UB was particularly high (Kruskal-Wallis test, $p<0.05$ ), caused by increased abundance of cladocerans, copepods and largebodied rotifer (e.g. Asplanchna priodonta). This indicates that even in shallow water bodies vertical migration against visual predators existed (Castro et al., 2007). The intensity of vertical migration in this study was most pronounced by cladoceras, indicated by their increased abundance at the bottom in relation to the surface water layer of the UB. This vertical migration of microfilter-feeder cladoceras provided optimal conditions for microfilter-feeder rotifers development in the surface water layer of the UB (Špoljar et al., 2011).

Interaction of abiotic and biotic factors in the UB enabled optimal conditions for development of numerous r-strategist rotifer populations in the food-rich environment in the pelagial surface water layer of the UB (Lapesa et al., 2002; Kuczyńska-Kippen, 2007). Although in this study horizontal migrations of zooplankton were not considered, it was presumed that low abundance of cladocerans and absence of large-bodied ones in the surface water layer of the UB was a consequence of their horizontal migration in macrophyte covered littoral zone (Kuczyńska-Kippen and Nagengast, 2006; Estlander et al., 2009). Thus, negative correlation between transparency and cladocerans abundance $(r=-0.46$, $p<0.05$ ) can be explained by their escape in the littoral zone or bottom water layer. Absence of large-bodied cladocerans in the UB is in concordance with results reported by other authors and size efficiency theory where large-bodied individuals were first eliminated, due to the fish prey selectivity (Estlander et al., 2009).

In the LB, turbidity was the most significant factor in the zooplankton structuring. Fish predation pressure was reduced and large-bodied cladocerans appeared, although small planktonic cladocerans prevailed in abundance. Considering copepods, their fast movement is an efficient tool against fish predation (Špoljar et al., 2012). Appearance and abundance of juvenile perch negatively affected copepods, while adult perch is a much more efficient predator than 
other planktivorous fish (Horpilla et al., 2000; Piria et al., 2005; Nurminen et al., 2007). High turbidity, reduced fish predation and plenty of food resources in the pelagial of the LB allowed abundant growth of detritivorous cladocerans (Bosmina longirostris) and resulted in rotifers suppressing (Špoljar et al., 2011). Also, B. longirostris consumess a wider range of food and is competitively dominant in presented conditions in relation to detritivorous rotifers.

Results of Castro et al. (2005) and Miracle et al. (2007) suggest that higher TSI, turbidity and the absence of submerged macrophytes may result in reduced abundance and diversity of zooplankton, which is in accordance with our results. Therefore, lower abundance and diversity of zooplankton in the LB was found as the result of macrophyte absence in the littoral zone and depletion of food resources. Simultaneously, by increasing trophic level, diversity is reduced and abundance of detritivorous species increased (May and O'Hare, 2005). Results of our study indicated different zooplankton structures in view of diversity, abundance and functional feeding guilds in two interconnected basins, caused by the multiple interaction of biotic (predation, macrophytes) and abiotic (turbidity, nutrient concentrations) factors. The importance of macrophytes as the main factor governing ecosystem functioning is emphasized.

\section{Sažetak}

\section{STRUKTURA ZOOPLANKTONA U MEĐUSOBNO POVEZANIM PLITKIM JEZERIMA}

Istraživanje raznolikosti, abundancije i trofičke strukture zooplanktona provedeno je tijekom vegetacijskog razdoblja na pelagičkim postajama longitudinalnog profila rukavca rijeke Sutle koji se sastoji od dva međusobno povezana bazena. Gornji bazen veće je prozirnosti i sa submerznim sastojinama makrofita, Donji bazen veće je mutnoće i bez makrofita. U Gornjem bazenu, brojnost i raznolikost zooplanktona u pelagijalu je bila veća u odnosu na Donji bazen, a prevladavali su kolnjaci, detritivorni-mikrofiltratori roda Keratella i algivorni-makrofiltratori rodova Polyartha i Trihocerca. U Donjem bazenu brojnost planktonskih rakova bila je veća u odnosu na Gornji bazen, a prevladavali su mikrofiltratorski rašljoticalci (Bosmina longirostris) te makrofiltratorski ličinački i adultni stadiji veslonožaca (Macrocyclops albidus). Predacijski pritisak riba bio je izraženiji u pelagijalu Gornjeg bazena, na što ukazuje manja brojnost Cladocera u površinskom sloju. lako su istraživani bazeni međusobno povezani, rezultati rada ukazuju na značajne razlike (MannWhitney $\mathrm{U}$ test, $\mathrm{p}<0.05$ ) u strukturi zooplanktona kao rezultat utjecaja makrofita i predacije riba na promjenu uvjeta okoliša.

Ključne riječi: submerzni makrofiti, prozirnost, mutnoća, predacija, ribe

\section{REFERENCES}

APHA (1998): Standard methods for the examination of water and wastewater, $20^{\text {th }}$ edition American Public Health Association, Washington, D.C. 1325pp.

Beklioglu, M., Ince, O., Tuzun, I. (2003): Restoration of the eutrophic lake Eymir, Turkey, by biomanipulation after a major external nutrient control I. Hydrobiologia, 490, 93105.

Carlson, R. E. (1977): A trophic state index for lakes. Limnology and Oceanography, 22, 361-369.

Castro, B. B., Antunes, S. C., Pereira, R., Soares, A. M. V. M., Gonçalves, F. (2005): Rotifer community structure in three shallow lakes: seasonal fluctuations and explanatory factors. Hydrobiologia, 543, 221-232.

Castro, B. B., Marques, S. M., Gonçalves, F. (2007): Habitat selection and diel distribution of the crustacean zooplankton from a shallow Mediterranean lake during the turbid and clear water phases. Freshwater Biology, 52, 421-433.

Cazzanelli, M., Warming, T. P., Christoffersen, K. S. (2008): Emergent and floating-leaved macrophytes as refuge for zooplankton in a eutrophic temperate lake without submerged vegetation. Hydrobiologia, 605, 113-122.

Céréghino, R., Biggs, J., Oertli, B., Declerck, S. (2008): The ecology of European ponds: defining the characteristics of a neglected freshwater habitat. Hydrobiologia, 597, 1-6.

Cottenie, K., Nuytten, N., Michels, E., De Meester, L. (2001): Zooplankton community structure and environmental conditions in a set of interconnected ponds. Hydrobiologia, 442, 339-350.

Einsle, U. (1993): Crustacea: Copepoda: Calanoida und Cyclopoida. In: Schwoerbel, J., Zwick, P. (eds.), Süsswasserfauna von Mitteleuropa. Gustav Fischer Verlag, Berlin, 209 pp.

Estlander, S., Nurminen, S. L., Olin, M., Vinni, M., Horppila, J. (2009): Seasonal fluctuations in macrophyte cover and water transparency of four brown-water lakes: implications for crustacean zooplankton in littoral and pelagic habitats. Hydrobiologia, 620, 109-120.

Feldmann, T., Nõges, P. (2007): Factors controlling macrophyte distribution in large shallow Lake Võrtsjärv. Aquatic Botany, 87, 15-21.

Gliwicz, Z. M., Rutkowska, A. E., Wojciechowska, J. (2000): Daphnia populations in three interconnected lakes with roach as the principal planktivore. Journal of Plankton Research, 22, 8, 1539-1557.

Horppila, J., Nurminen, L. (2005): Effects of different macrophyte growth forms on sediment and $\mathrm{P}$ resuspension in a shallow lake. Hydrobiologia, 545, 167-175.

Horppila, J., Ruuhijärvi, J., Rask, M., Karppinen, C., Nyberg, K., Olin, M. (2000): Seasonal changes in the diets and relative abundance of perch and roach - a comparison 
between littoral and pelagic zones of a large lake. Journal of Fish Biology, 56, 51-72.

Jeppesen, E., Jensen, J. P., Søndergaard, M., Lauridsen, T. (1999): Trophic dynamics in turbid and clearwater lakes with special emphasis on the role of zooplankton for water clarity. Hydrobiologia, 408/409, 217-231.

Karabin, A. (1985): Pelagic zooplankton (Rotatoria + Crustacea) variations in the process of lake eutrophication. II. Modifying effect of biotic agents. Ekologia Polska, 33, 617-644.

Kruk, C., Rodríguez-Gallego, L., Meerhoff, M., Quintans, F., Lacerot, G., Mazzeo, N., Scasso, F., Paggi, J. C., Peeters, T. H. M. E., Scheffer, M. (2009): Determinants of biodiversity in subtropical shallow lakes (Atlantic coast, Uruguay). Freshwater Biology, 54, 2628-2641.

Kuczynska-Kippen, N. (2007): Habitat choice in rotifers communities of three shallow lakes: impact of macrophyte substratum and season. Hydrobiologia, 593, 27-37.

Kuczy ska-Kippen, N. M., Nagengast, B. (2006): The influence of the spatial structure of hydromacrophytes and differentiating habitat on the structure of rotifer and cladoceran communities. Hydrobiologia, 559, 203-212.

Lapesa, S., Snell, T. W., Fields, D. M., Serra, M. (2002): Predatory interactions between a cyclopoid copepod and three sibling rotifer species. Freshwater Biology, 47, 1685-1695.

Margaritora, F. (1983): Cladoceri. Guida per il riconoscimento delle specie animali delle acque interne italiane, 22. Consiglio Nazionale delle Ricerche, Verona. 169pp.

May, L., O'Hare, M. (2005): Changes in rotifer species composition and abundance along a trophic gradient in Loch Lomond, Scotland, UK. Hydrobiologia, 546, 397-404.

Mičetić, V., Bučar, M., Ivković, M., Piria, M., Krulik, I., Mihoci, I., Delić, A., Kučinić, M. (2008): Feeding ecology of Sabanejewia balcanica and Cobitis elongata in Croatia. Folia Zoologica, 57, 1-2, 181-190.

Michels, E., Cottenie, K., Neys, L., De Meester, L. (2001): Zooplankton on the move: first results on the quantification of dispersal of zooplankton in a set of interconnected ponds. Hydrobiologia, 442, 117-126.

Miracle, M. R., Alfonso, M. T., Vicente, E. (2007): Fish and nutrient enrichment effects in a Mediterranean shallow lake: a mesocosm experiment. Hydrobiologia, 593, 7794.

Nurminen, L., Horppila, J., Pekcan-Hekim, Z. (2007): Effect of light and predator abundance on the habitat choice of plant-attached zooplankton. Freshwater Biology, 52, 539-548.

Nusch, E. A. (1980): Comparison of different mehods for chlorophyll and phaeopigment determination. Ergebnisse der Limnologie, 14, 14-36.

Piria, M., Treer, T., Aničić, I., Safner, R., Odak, T. (2005): The Natural Diet of Five Cyprinid Fish Species. Agriculturae Conspectus Scientificus, 70 (1): 21-28.

Scheffer, M., Hosper, S. H., Meijer, M. L, Moss, B., Jeppesen, E. (1993): Alternative equilibria in shallow lakes. Trends in Ecology \& Evolution, 8, 275-279.

Søndergaard, M., Jeppesen, E., Lauridsen, T. L., Skov, C., Van Nes, E. H., Roijackers, R., Lammens, E., Portielje, R. (2007): Lake restoration: successes, failures and longterm effects. Journal of Applied Ecology, 44, 1095-1105.

Stemberger, R. S., Gilbert, J. J. (1984): Spine development in the Keratella cochlearis: induction by cyclopoid copepods and Asplanchna. Freshwater Biology, 14, 639-647.

Špoljar, M. (2013): Microaquatic communities as indicator of environmental changes in lake ecosystems. Journal of Engineering Research, 1, 29-42.

Špoljar, M., Habdija, I., Primc-Habdija, B. (2007): The Influence of the Lotic and Lentic Stretches on the Zooseston Flux through the Plitvice Lakes (Croatia). Annales de Limnologie, 43, 1, 29-40.

Špoljar, M., Dražina, T., Habdija, I., Meseljević, M., Grčić, Z. (2011): Contrasting zoplankton assemblages in two oxbow lakes with low transparencies and narrow emergant macrophyte belts (Krapina River, Croatia). International Review of Hydrobiology, 96, 175-190.

Špoljar, M., Dražina, T., Šargač, J., Kralj-Borojević, K., Žutinić, P. (2012): Submerged macrophytes as a habitat for zooplankton development in two reservoirs of a flow-through system (Papuk Nature Park, Croatia). Annales de Limnologie - International Journal of Limnology, 48, 161-175.

Voigt, M., Koste, W. (1978): Die Rädertiere Mitteleuropas. Gebrüder Borntraeger. Berlin, Stuttgart. 673pp. 